\title{
A Study on the Level of Adoption in Production Practices of Certified Seeds by the Respondents in Selected Crops (Paddy, Wheat)
}

\author{
Vishesh Gupta* and Syed H. Mazhar
}

Department of Agricultural Extension and Communication, SHUATS, Prayagraj, Uttar Pradesh, India

*Corresponding author

\begin{abstract}
A B S T R A C T
Keywords

Adoption,

Production

Practices and

certified seeds

Article Info

Accepted:

20 December 2020

Available Online:

10 January 2021

Seed is the most crucial input in the crop production cycle. This paper is based on the primary survey of 80 farmers in the five states in the indogenetic plains, and has analysed the various factors responsible for the adoption of new wheat seed varieties by the farmers. Certified seed is produced from the seed of known genetic origin and genetic purity with controlled and tested production, processed and declared in accordance with the law on seeds. Production of certified seed is carried out under the ministry of agriculture and environmental protection, by seed producers formally listed in the seed register.

\section{Introduction}

The major problems of the devolving countries in the ne millennium are the rising population and depletion natural resources besides pollution and poverty. Indian agriculture in facing uphill task in providing the food security to ever increasing population of our country with the application of improved seeds. Food production increased from 60 million tonnes in 2005-2006over 200 mt. in 2018-2019. This features was may reach up to 210 million tonnes but cannot reached because due to drought in the year (2002-2003). The food requirement for the

expanding population (1.3) billion by 2020. In estimated at 266.4 and 343 million tonnes by 2010 \&amp; 2020respectively based on consumption of 2200 calories/day/person. Against the over 200 million tonnes of existing food grain production in 2018-2019. To make India a food secrure nation it is necessary either to put more area under cultivation or increase the productivity of exiting agricultural crops. But, due to increase pressure of urbanization and industrialization, cultivated land is shrinking day by day. Therefore to increase the productivity of exiting agriculture is the only possible solution to meet our food requirement. This
\end{abstract}


aim can be possible an a result of the adoption of good quality seeds, enhanced use of fertilizer and plant protection practice, besides assumed irrigation. The use of quality seeds by farmers had increased to 22 lakh tonnes in 2010-2011 against 6.5 lakh tonnes during 2006-2008.

\section{Part I: To ascertain the socio-economic} profile of the respondents

To ascertain the socio -economic profile of the respondents for the selected area is studied under the following particulars.

Breeder seed

Foundation seed

Certified seed

seed viability

Physical pure seed

Contaminated seed

Seed health

Seed vigour

Seed germination

Source of seed

\section{There are four classes of seeds}

Breeder seed: The breeder seed is seed or vegetative propagating material which is directly controlled by the originating or in certain cases. The sponsoring breeder or institution and which provides for the initial and recurring increase of foundation seed.

Foundation seed: Foundation seed including "select" in Canada is seed stock so handled as to most nearly maintain specific genetic identity and purity and that may be designated or distributed by an agricultural experiment station.

Registered seed: Registered seed progeny of foundation or registered seed that is so handled as to maintain satisfactory genetic identity and purity, and that has been apposed and certified by certifying agency.

Certified seed: Certified seed is the progeny of foundation, that is so hand to maintain satisfactory genetic identity and purity and that has been approved and certified by the certifying agency.

\section{Materials and Methods}

District Kanpur Dehat of U.P was the locale of this study. The selection of District Kanpur Dehat was purposely made because the area comes under the jurisdiction of the CSA University of Agri. \&Tech. Kanpur.Data was collecting with the help of a structured schedule covering all aspects of the study. The researcher himself established report with each respondent at his residence and farm, or where ever he could be available.After the selection of respondents the nature of objectives prior to preparation of devices a field survey was necessary to get specific Knowledge of the area and the various problems of investigation.

Thus a pilot study was conducted to know about the awareness of the certified seeds, adoption of quality seeds and problems regarding utilization of certified seeds in respect of wheat and paddy crops. The Schedule was readjusted corrected and finalized in the light of the experience gained out of such pilot study.

\section{Results and Discussion}

The present study entitled Adoption Behaviour of Production Pratices of Certified seed Among the Farmers in Kanpur Dehat District (U.P) was conducted in two development blocks namely Malasaand Akabarpur.The Result and Discussion with respect to specific objectives are presented here under 
Adoption level of certified seed regarding paddy crops

It is clear from the above table that is highest majority $(90.0 \%)$ exit in low adopters category. Remaining 7.5 percent and 2.5 percent medium and high adopter categories. None of the farmers was found under the category of non-adopters.

Table.1 Awareness of respondents about certified seed

\begin{tabular}{|l|l|c|c|c|c|c|}
\hline S.No & Particulars & $\begin{array}{c}\text { Fully } \\
\text { Aware }\end{array}$ & $\begin{array}{c}\text { Less } \\
\text { Aware }\end{array}$ & NotAware & $\begin{array}{c}\text { Mean } \\
\text { Aware }\end{array}$ & Percentage \\
\hline $\mathbf{1}$ & Breederseed & 0 & 0 & 80 & 1.00 & $\mathbf{3 3 . 3}$ \\
\hline $\mathbf{2}$ & Foundationseed & 0 & 5 & 75 & 1.06 & $\mathbf{3 5 . 3}$ \\
\hline $\mathbf{3}$ & Certifiedseed & 24 & 21 & 35 & 1.86 & $\mathbf{6 2}$ \\
\hline $\mathbf{4}$ & Seedgermination & 20 & 33 & 27 & 1.91 & $\mathbf{6 3 . 6}$ \\
\hline $\mathbf{5}$ & Seedviability & 0 & 1 & 79 & 1.01 & $\mathbf{3 3 . 6}$ \\
\hline $\mathbf{6}$ & Physicalpureseed & 0 & 18 & 62 & 1.22 & $\mathbf{4 0 . 6}$ \\
\hline $\mathbf{7}$ & Contaminatedseed & 0 & 15 & 65 & 1.18 & $\mathbf{3 9 . 3}$ \\
\hline $\mathbf{8}$ & Seedhealth & 35 & 22 & 23 & 2.15 & $\mathbf{7 1 . 6}$ \\
\hline $\mathbf{9}$ & Seedvigour & $\mathbf{0}$ & $\mathbf{0}$ & $\mathbf{8 0}$ & $\mathbf{1 . 0 0}$ & $\mathbf{3 3 . 3}$ \\
\hline
\end{tabular}

$\mathrm{n}=80$

Table.2 The level of the knowledge of the respondents regarding practices of certified seeds for two crops was calculated with the help pf adoption quotient (A.Q)

\begin{tabular}{|c|c|c|c|}
\hline S.No. & Adoption category & No. of respondents & Percentage \\
\hline $\mathbf{1}$ & Non adopters $(0)$ & 0 & 0 \\
\hline $\mathbf{2}$ & Low adopter $(0,1-30)$ & 72 & 90.0 \\
\hline $\mathbf{3}$ & Medium adopter $(30,1-60)$ & 6 & 7.5 \\
\hline $\mathbf{4}$ & High adopter $(60,1-100)$ & 2 & 2.5 \\
\hline
\end{tabular}

Table.3 Adoption level of certified seed regarding wheat crop

\begin{tabular}{|c|c|c|c|}
\hline S.No. & Adoption Category & No. of respondents & Percentage \\
\hline $\mathbf{1}$ & Non-adopters $(0)$ & 0 & 0 \\
\hline $\mathbf{2}$ & Low adopters $(0,1-30)$ & 73 & 91.25 \\
\hline $\mathbf{3}$ & Medium adopters $(30,1-60)$ & 3 & 3.75 \\
\hline $\mathbf{4}$ & High adopters $(60,1-100)$ & 4 & 5.00 \\
\hline
\end{tabular}



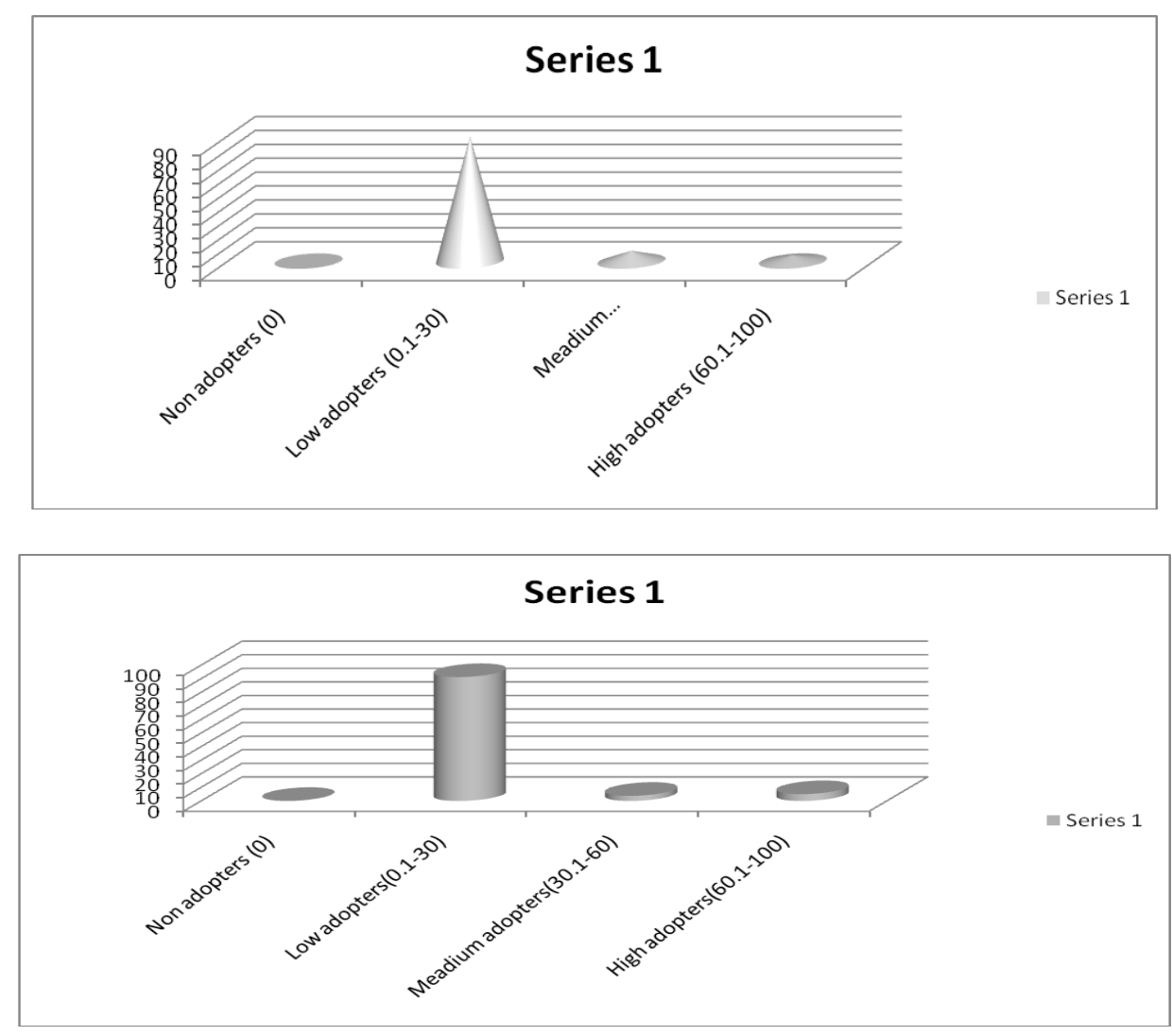

Thus, it is concluded that almost all the farmers were using certified seed. This show that farmers of the locality are very much aware about the important of certified seeds but they are using in a very few amount. It is apparent from above table that the majority (91.25 percent) of farmers was under low adopter's category. Remaining 5.00 and 3.75 percent belonged to high and low adopter's categories. None of the farmers was found under non-adopters category.

Therefore, it in clear from the above result that majority of the farmers belonged to low level category about addition of certified seeds. This is only due to non-availability of certified seed.

On the basis of findings the following conclusion has been draw:

Most of the respondents were having maximum awareness about seed health, lowest awareness recorded in breeder seed, seed vigour and seed viability. Cent percent respondents were using their own seed and only few respondents were using standard agency's seed.

Maximum respondents were faced the major problems like lack of awareness about certified seed, lack of knowledge about production of certified seed, Adulteration in seed by private agencies and non cooperation of insurance company for adoption of certified seed.

Maximum respondents belonged to low adopters category of adoption of certified seed in paddy and wheat crops.

\section{References}

Asiwal, B. L. (2006). Impact of front line demonstration on adoption of improved mustard production technology among 
the farmers of Laxamangarh Panchayat Samity of Sikar district of Rajasthan. M.Sc.(Ag.) Thesis SKRAU, campusJobner.

Asiwal, B.L.; Sangramsingh and Sharma, N.K. (2013). Adoption gap and constraints in adoption of improved mustard production technology in semi arid region of Rajsthan. Ind. J. Extn. Edu. and R.D., 21:105-108.

Badhala, B.S.; and Jat, H.L. (2014). Association between adoption of beneficiary and non- beneficiary farmers with respect to groundnut production technololoy. Ind. J. Social Res. 55 (1): 123-128.

Choudhary, P.C. (2008). Impact of olericultural interventions introduced in technology assessment and refinement under Intuitions Village Linkage Programme in Ajmer District of Rajasthan. Ph.D. Thesis, SKRAU, Bikaner, Campus: Jobner.

Dhayal, B.L. (2006). Communication behaviour of ber growers in Chomu Tehsil of Jaipur District of Rajasthan. M.Sc. (Ag.) Thesis SKRAU, Bikaner,
Campus: Jobner.

English, H.B. and English, A.B. (1961). Comprehensive dictionary of psychological terms. New York longmans Green and Company

Guilford, (1954). www.guilfordjournals.com > Social Cognition Harshim, S.R. (1989). Rural development the Indian experience. Yojana, 33 (14-15) : 34-38.

Jadhav, K.K. and Aski, S.G. (2014) knowledge level of farmers about improved redgram production technologiesa Ag. update : 9(3) : 8 : 2014, 337-341.

Jha, S.K.; Sharma, A.K.; Kumar, V.; Sachan, R.C. and Kumar, A. (2005). Problems and strategy for mustard production in Bharatpur district of Rajasthan. Ind. Res. J. Extn. Edu., 5 (1) : 18-20.

Kaid, S.V. (2004). Technological gap in kharif fennel cultivation by fennel growers in Punapar Taluk of Banaskantha district of Gujarat state. M.Sc. (Ag.) Thesis, G.A.U., Campus: S.K.Nagar.

\section{How to cite this article:}

Vishesh Gupta and Syed H. Mazhar. 2021. A Study on the Level of Adoption in Production Practices of Certified Seeds by the Respondents in Selected Crops (Paddy, Wheat). Int.J.Curr.Microbiol.App.Sci. 10(01): 3334-3338. doi: https://doi.org/10.20546/ijcmas.2021.1001.391 